\title{
配位子交換クロマトグラフィーによるアミノ安息香酸 異性体の分離*
}

\author{
舟 阪 渡，藤村 一美，栗山 智**
}

(1969 年 7 月 29 日受理)

銅（II）形の強酸性陽イオン交換樹脂ならびに希薄なアンモニア水または水をそれぞれ固定相ならび に移動相に使用する配位子交換クロマトグラフィーにより，アミノ安息香酸異性体を分離する方法につ いて検討した。

液相中においては, $\mathrm{Cu}^{2+}$ の濃度が比較的高く，かつ $\mathrm{Cu}^{2+}$ に対してアミノ安息香酸が多量に存在す る場合には，各異性体とも緑色の不溶性錯体を形成したが， $\mathrm{Cu}^{2+}$ の濃度が低く $\left(1 \times 10^{-3} M\right.$ 以下), 乙 かもアミノ安息香酸の量が $\mathrm{Cu}^{2+}$ に対してモル比で 1:1 以下のときには無色の可溶性錯体が生成し た.なかでも， 0 -アミノ安息香酸は他の異性体よりも安定な錯体を形成したために，銅 (II) 形樹脂に 対する分配係数は著しく大となったまた配位子交換速度は， $m$ 一異性体のみがほかの異性体と異なり， 吸着速度は小さく，逆に脱着速度は大となったが，これは銅-m-アミノ安息香酸錯体の構造に基因する ものと考えられた。 o- および $m$-異性体, あるいは 0 -および $p$-異性体のクロマトグラフ分離には, $\phi 14 \mathrm{~mm} \times 390 \mathrm{~mm}$ のカラムを使用し, pH 8.4 のアンモニア水で溶離を行なえば，それぞれが良好に 分離できた。しかしながら $m$ - および $p$-異性体相互の分離には, 両者ともアンモニア水中での分配係 数が著しく小さいので, 純水を溶離液として用いる必要があった。さらに, 銅-o-アミノ安息香酸錯体 のアンモニア水中における安定性の検討から, 水酸化ナトリウム水溶液も溶離液として使用しうること が示唆された。

\section{1 緒 言}

有機化合物の異性体の分離に際して，てれらが金属イ オンと錯体を形成しうる物質である場合には，錯形成能 注異性体によって異なる場合が多いので，配位子交換ク ロマトグラフィーがきわわて有効となる・著者らはすで に，フェニレンジアミンの異性体の分離にこの配位子交 換クロマトグラフィーを適用し，鉄 (III) 形の強酸性陽 イオン交換樹脂ならびに希薄なアンモニア水をそれぞれ 固定相および移動相に使用することによって，各異性体 が完全に分離できることを見いだした1．てこで今回は この方法をアミノ安息香酸異性体の相互分锥にも邀用し たところ良好な結果が得られたのだここ机について報告 する.

アミノ安息香酸異性体のうちでも，0-異性体法銅，亚 鉛, ニッケルなどの重金属イオンと不溶性のキレートを

* 配位子交換クロマトグラフィーに関する研究（第 2 報). 第 1 報泟舟阪 渡, 藤村一美, 栗山 智: 本 誌, 18, 19 (1969)

** 京都大学工学部工業化学教室 : 京都市左京区吉田本 町
形成するために, 従来より重金属イオンの沈殿定量試薬 として用いられてきているが273)，m-少よび $p$-異性体 の錯形成能についての研究はほとえど見あたらない。一 方, アミノ安息香酸異性体の分離に関しては, 沪紙ク口 マトグラフィーなどによるもの4う5）の涼かに，塭析クロ マトグラフィー6)を利用する研究がある。

\section{2 実験方法}

\section{1 試料およびイオン交換樹脂}

アミノ安息香酸は, 市販の特級品または二の同等品を さらにエタノール（o-抒よび $m$ 一異性体）また㳊純水 ( $p$-異性体) 中より再結晶をくりかえして精製したのち 実験に供した。精製品の融点は $o$-異性体: $146^{\circ} \mathrm{C}, m$ 異性体： $174^{\circ} \mathrm{C}, p$-異性体：186 ${ }^{\circ} \mathrm{C}$ で，いずれ气文献值 $\left(o-: 146.1^{\circ} \mathrm{C}, m-: 174^{\circ} \mathrm{C}, p-: 186 \sim 187^{\circ} \mathrm{C}\right)$ とよく 一致していた。試料溶液は各異性体とも，固体 0.1371 $\mathrm{g}$ を 30\% エタノールに溶かして $100 \mathrm{ml}$ としたもの $\left(1 \times 10^{-2} M\right.$ 溶液) を標準溶液とし，これを適宜希釈し て用いた．試料溶液はかっ色びんに入れて暗所にたくわ えた。

一方，イオン交換樹脂は塩化第二銅水溶液によって銅 （II）形とした強酸性陽イオン交換樹脂 Amberlite CG120 を使用し, バッチ法にはこれの 100〜200メッシュ 
のものを，またカラム法には 200〜400メッシュのもの を使用した。このほか溶離液にはアンモニア水を選び, 市販の特級品を適当な濃度に希釈して使用した。

\section{2 定量方法}

アミノ安息香酸の定量壮紫外部における吸収を利用 し, 吸光光度法で行なった. 装置は島津光電分光光度計 QV-50を使用し，測定には $1.00 \mathrm{~cm}$ の石英セルを用い た.

\section{3 分配係数の測定}

溶離液として使用するアンモニア水中におけるアミノ 安息香酸の銅 (II) 形樹脂に対する分配係数は, バッチ 法によって，室温で測定した。すなわち，容積 $50 \mathrm{ml}$ の ふっ色せ九付きフラスコ 6〜8 個に 100〜200 メッシュ

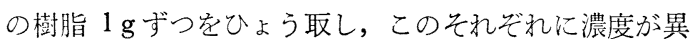
ふったアンモニア水 $25 \mathrm{ml}$ を加えて約 1 時間ゆるやかに 振り混ぜ，樹脂と溶液とを平衡化させた.ついでアミノ 安息香酸の $4 \times 10^{-3} M$ 溶液を $1 \mathrm{ml}(0.5486 \mathrm{mg}$ を含む) 加え，ふたたびじゅうぶえに振り混ぜたのち 24 時間放 置し, 配位子交換平衡に到達させた. そののちグラスフ ィルター（3G-2）を用いて吸引することなく樹脂を分 離し, 沪液の吸光度を測定して平衡濃度ならびに樹脂に 捕集された量を求め, $K_{d}=\mathrm{M}_{\mathrm{R}} / \mathrm{M}_{\mathrm{S}} \times v / m$ の関係に従っ て分配係数を算出した。 ただし $\mathrm{M}_{\mathrm{R}}, \mathrm{M}_{\mathrm{S}}$ はそれぞれ樹 脂相および溶液相中のアミノ安息香酸の量を, また $m$ は イオン交換樹脂の重量を, さらにvは溶液相の体積を表 わす。

\section{4 カラムの作製}

ビーカーに 200〜400メッシュの銅 (II) 形樹脂它と り，これに純水を加えて膨㵎させたのち，さらに $6 N$ ア ンモ二ア水を適当量加えてじゅうぶえにふき混ぜ, 溶離 液として使用するアンモニア水の $\mathrm{pH}$ 值と同じ $\mathrm{pH}$ 值 において樹脂堂溶液と平衡化させた，そののち樹脂と溶 液之学分離し，樹脂はクロマト管に詰めてカラムを作製 した.この場合, 銅 (II) 形の樹脂に純水を加えて膨潤 させると, 液相の $\mathrm{pH}$ 值は約 5 となるが，これに希アン モニア水を少量加えても樹脂は水酸イオンもしくはアン モニア分子を鍇吸着与るため液相の $\mathrm{pH}$ 值法あまり变化 しない・したがって銅（II）形樹脂を詰めたカラムに， あらかじめ $\mathrm{pH}$ 值を調節しておいたアンモニア水它流し て樹脂を溶液と平衡化させる場合には, 多量の溶液が必 要となるし，また平衡に至るまでには長時間を要するの で適当ではない。

\section{3 結果および考察}

\section{1 吸光係数と $\mathbf{p H}$ 亡の関係}

アミノ安息香酸を吸光光度法によって定量する際の測 定波長を選定するために, $\mathrm{pH}$ 值が異なるアンモニア水 中において, 波長 $250 \sim 350 \mathrm{~m} \mu$ の範囲で吸収スペクト ルを描いてみた. その結果, 各異性体ともスペクトルの 形は pH 8 以上ではまったく変化しないことが羿的られ た.したがって測定波長としては，各異性体の極大吸 収波長, すなわち， 0 -異性体: $310.0 \mathrm{~m} \mu, m$-異性体 : $300.0 \mathrm{~m} \mu$ ，p-異性体： $265.0 \mathrm{~m} \mu$ を採用することにした。 ここで選定した波長における吸光係数と $\mathrm{pH}$ 值との関係 は Fig. 1 のようである. Fig. 1 より明らかなように, $\mathrm{pH}$ が 8 より小になるにしたがって吸光係数は減少する が，pH 8 以上では一定となることが訫められる。

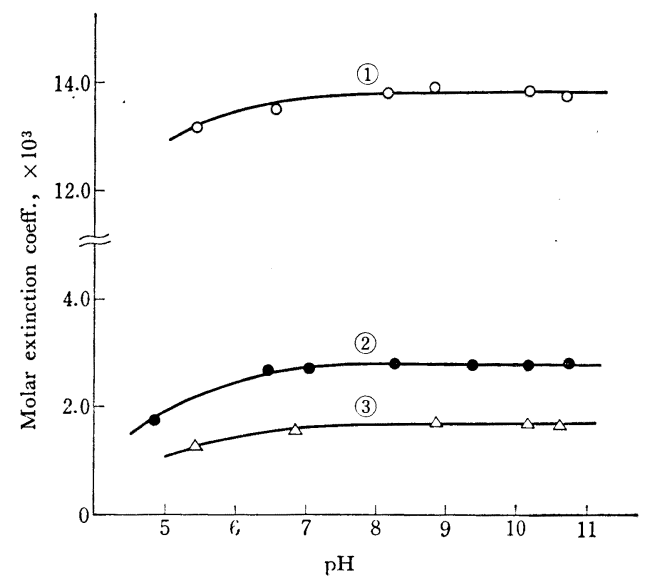

Fig. 1 Relationship between molar extinction coefficient and $\mathrm{pH}$

(1) $p$-Isomer $\left(265.0 \mathrm{~m}_{\mu}\right)$; (2) o-Isomer $\left(310.0 \mathrm{~m}_{\mu}\right)$;
(3) $m$-Isomer $\left(300.0 \mathrm{~m}_{\mu}\right)$

\section{2 分配係数}

アンモニア分子もしくは水酸イオンを錯吸着した銅 (II) 形の Amberlite CG-120 に対するアミノ安息香酸 の分配係数は Fig. 2 のようになった.

分配係数祳度が種々に異なるアンモニア水中で測定 し，アンモニアの平衡濃度を $\mathrm{pH}$ 值で表わしたが，各異 性体ともアンモニアの濃度が増大するにしたがって分配 係数注減少する傾向がみられ，特に はこの傾向が著しい. しかも $o$-異性体の分配係数は $m$ および $p$-異性体に比べて, $\mathrm{pH} 9$ 以下では特に大きい 值となるので, $m$ - 就よ゙ $p$-異性体からの分離は容易で 


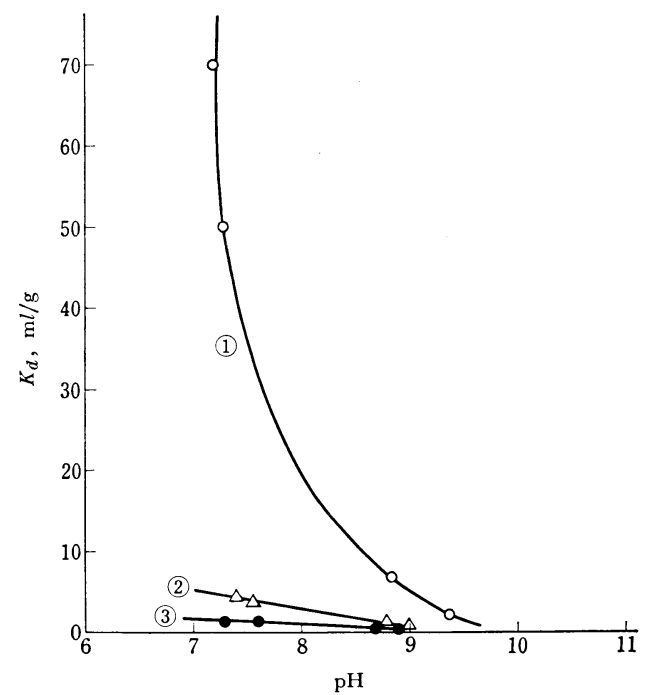

Fig. 2 Distribution coefficient of aminobenzoic acid on Amberlite $\mathrm{CG}-120 \mathrm{Cu}^{2+}$ form (1) $o$-Isomer ; (2) $m$-Isomer; (3) $p$-Isomer; Solvent : Aqueous ammonia

あると思われる。しかしながら $m$-および $p$-異性体の 分配係数は両方とも非常に小さく, しかも分離係数も $\mathrm{pH}$ 7〜8 の範囲ではそれほど大きくはないので, 両者 の分離は非常に困難であると考えられる.このように $o$-異性体の分配係数が $\mathrm{pH} 8$ 以下では非常に大となる ことから，この条件下では銅-o-アミノ安息香酸錯体の 安定度定数が大となることが予想でき, また実際にo異性体が微酸性の溶液中で重金属イオンの沈殿定量試薬 として利用されることとも関連していると考えられる.

\section{3 配位子交換速度}

すでに検討を行なったフェニレンジアミンの鉄（III） 形樹脂に対する吸着速度1 は，特に $p$-異性体において 著しく小さいため，これが原因となってクロマトグラフ ィ一の際に保持容量が溶離液流速によって変化すること を認めた，そこでアミノ安息香酸の場合についても，単 に吸着速度だけでなく脱着速度をも測定してみた。

3.3.1 吸着速度 アンモ二ア水中で水酸イオン, ア ンモニア分子などを錯吸着して，pH 7.5〜7.6で平衡 化している銅 (II) 形の樹脂に対するアるノ安息香酸の $24^{\circ} \mathrm{C}$ における吸着速度を測定したところ，Fig. 3 のよ うになった。

Fig. 3 ではアミノ安息香酸と樹脂との接触時間に対し て, 樹脂 $1 \mathrm{~g}$ に対する吸着量を, 吸着平衡に到達したの 方（24 時間後）の吸着量に対する百分率で示している

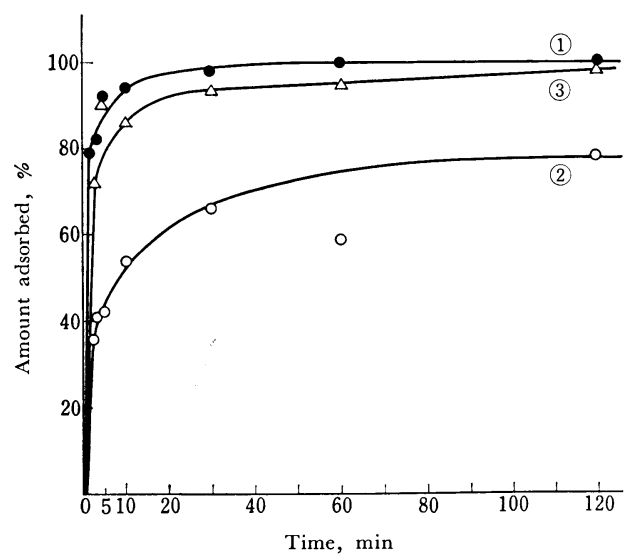

Fig. 3 Rate of adsorption of aminobenzoic acid in aqueous ammonia at $24^{\circ} \mathrm{C}$

(1) $o$-Isomer; (2) $m$-Isomer; (3) $p$-Isomer; Resin : Amberlite $\mathrm{CG}-120, \mathrm{Cu}^{2+}$ form; Solvent : Aqueous ammonia ( $\mathrm{pH} 7.5,7.6)$

が，Fig. 3 から明らかなように $o$-および $p$-異性体の場 合には，吸着率は約 10 分で $90 \%$ 以上になり，比較的 すみやかに平衡に達した。これに対して $m$-異性体の場 合には 10 分で 55\%，120 分後においても $80 \%$ 弱で あり，吸着速度が小であることが認められた。

3.3.2 脱着速度 希アンモニア水中において, $\mathrm{pH}$ 7.6 で平衡化させた銅 (II) 形樹脂にアミノ安息香酸を 錯吸着させたのち，pH 11.0 のアンモニア水を加え， 水酸イオンもしくはアンモニア分子との配位子交換反応 によってアミノ安息香酸が樹脂から脱離して液相中に出

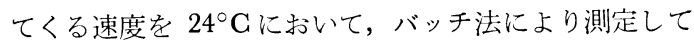
みると, Fig. 4 のようになった。

Fig. 4 では, 最初の吸着量に対する一定時間後の吸着 量の割合を時間に対して示しているが，o-および $m$-異 性体では 10 分で約 $60 \%$ が脱着され，さらに $m$-異性 体では 60 分で 100\% 脱着されるのに対して，O-およ び $p$-異性体は 120 分後においてもわずかながら樹脂中 に残存していることがわかった。 なお，120 分後におけ る液相の $\mathrm{pH}$ 值は 9.2 9.3であった. 本来, $\mathrm{pH} 9.2$ 9.3 のアンモニア水中に打いては, Fig. 2 に示した分配 係数の測定結果よりも明らかなように，平衡状態に到達 していれば，O-異性体ではわずかながら吸着が認めら礼 るけれども， $m$-および $p$-異性体では吸着性は認めら れないはずである。したがって $p$-異性体の脱着速度の みがほかの異性体に比べてやや小さいと考えられる.

このように $m$-異性体がやや特異な挙動を示し, 吸着 速度が小さく，また脱着速度が大きくなった原因につい 


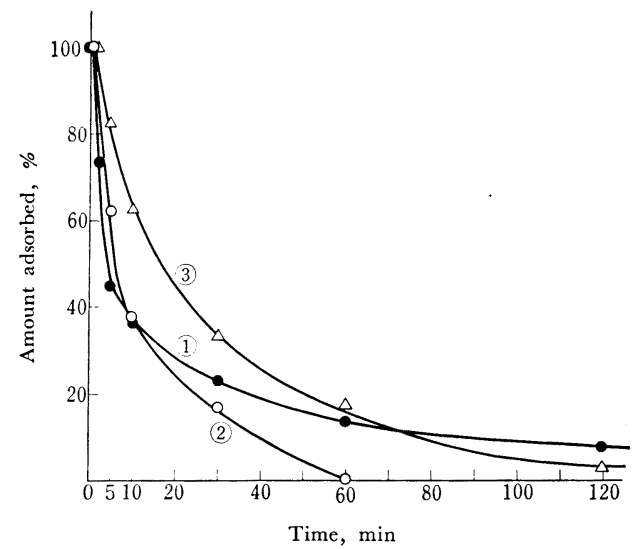

Fig. 4 Rate of desorption of aminobenzoic acid in aqueous ammonia at $24^{\circ} \mathrm{C}$

(1) $o$-Isomer ; (2) $m$-Isomer; (3) $p$-Isomer; Resin : Amberlite CG-120, $\mathrm{Cu}^{2+}$ form; Solvent : Aqueous ammonia ( $\mathrm{pH} 11.0)$

ては, 生成する錯体の構造によるものと考えられるの で，これについては3.6で考察するが，いずれにしても クロマトグラフィーの実施に際しては，分子拡散による 吸着バンドの広がりが無視できる程度においてできるだ け小さい流速で溶離することが必要と考えられる。

\section{4 クロマトグラフ分離}

3.4.1 o- および $\boldsymbol{m}$-異性体の分離 外径 $14 \mathrm{~mm}$, 長さ $390 \mathrm{~mm}$ のカラムに 0 - および $m$-異性体をそれぞ れ $0.02 \mathrm{mmol}$ ずつ含む試料液 $1 \mathrm{ml}$ を添加したのち, $\mathrm{pH} 8.4$ のアンモニア水を $0.3 \mathrm{ml} / \mathrm{min}$ の流速で流して 溶離を行なった．この場合のクロマトグラムを Fig. 5 に 示したが，両異性体の分離は完全であった。

なお，Fig. 5 の条件での回収率は，クロマトグラフィ 一を 3 回くりかえして平均值を求めたところ，o-異性体 では 94.3\%，m-異性体では 92.7\% であった。

3.4.2 o- および $\boldsymbol{p}$-異性体の分離 $\quad \phi 14 \mathrm{~mm} \times 390$ $\mathrm{mm}$ のカラムに $o$-異性体 $0.02 \mathrm{mmol}, p$-異性異 0.01 $\mathrm{mmol}$ を含む試料液 $1 \mathrm{ml}$ を添加したのち, $\mathrm{pH} 8.4$ の アンモニア水を用いて展開溶離を行なったところ，Fig. 6のようなクロマトグラムが得られた。 p - 異性体はやや テイリングの傾向を示したが，両者の分離は良好であっ た。回収率は $o$-異性体 : $95.8 \%, p$-異性体 : 90.0\%で あった。

3.4.3 $m$ - および $p$-異性体の分離 分配係数の測 定結果よりも明らかなように, 溶離液としてアンモニア 水を用いると，両異性体とも分配係数が著しく小となる

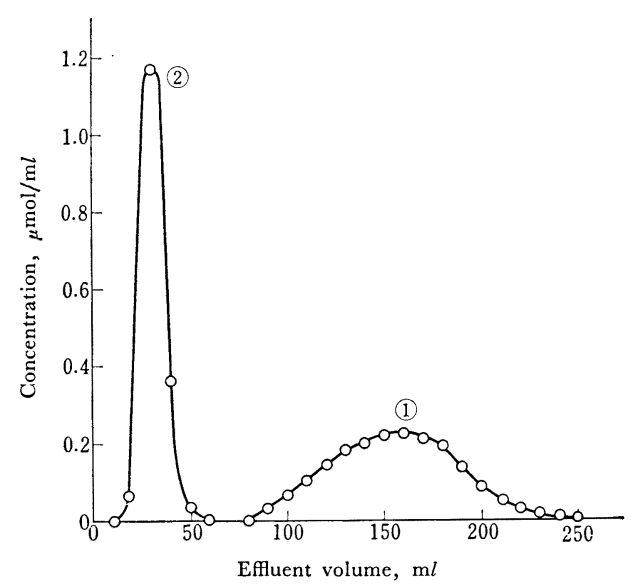

Fig. 5 Elution curves of $o$ - and $m$-aminobenzoic acids

(1) 0 -Isomer ; (2) $m$-Isomer; Column size : $\phi 14 \mathrm{~mm}$ $\times 390 \mathrm{~mm}$; Developer: Aqueous ammonia $(\mathrm{pH} \mathrm{8.4)}$; Flow rate : $0.3 \mathrm{ml} / \mathrm{min}$; Sample taken : $o$-Isomer $0.02 \mathrm{mmol}, m$-isomer $0.02 \mathrm{mmol}$; Recovery : $o$-Isomer $94.3 \%, m$-isomer $92.7 \%$

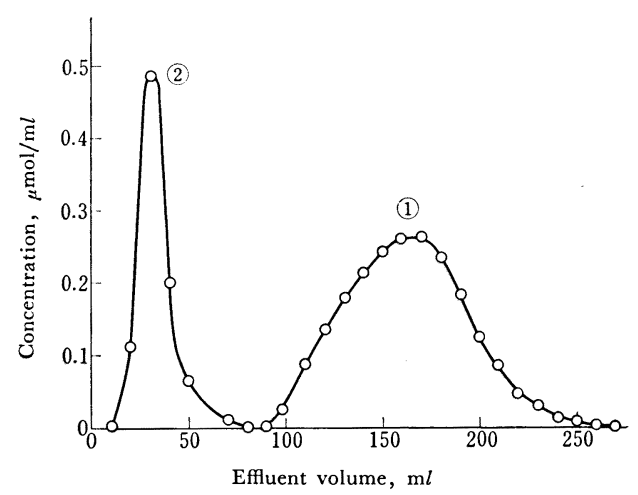

Fig. 6 Elution curves of $o$ - and $p$-aminobenzoic acids

(1) $o$-Isomer ; (2) $p$-Isomer ; Column size : $\phi 14 \mathrm{~mm} \times$

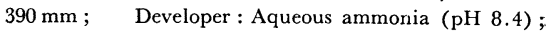
Flow rate : $0.3 \mathrm{ml} / \mathrm{min}$; Sample taken : $o$-Isomer $0.02 \mathrm{mmol}, p$-isomer $0.01 \mathrm{mmol}$; Recovery : $o$ Isomer $95.8 \%, p$-isomer $90.0 \%$

ので，分離注困難となる，それ沛え純水を溶離液として 用いることにした・すなわち，非常に希薄なアンモニア 水を用いて， $\mathrm{pH} 5.9$ で平衡化させた樹脂を $\phi 17 \mathrm{~mm}$ $\times 230 \mathrm{~mm}$ のクロマト管に詰めてカラムを作製し，これ に $m$-および $p$-異性体をそれぞれ $0.04 \mathrm{mmol}$ ずつ含 さ試料液 $1 \mathrm{ml}$ を添加したのち, 純水（pH 5.9）を 0.3 $\mathrm{m} l / \mathrm{min}$ の流速で流し展開溶離を行なった，この場合の クロマトグラムを Fig. 7 に示した. 
Fig.7 では，p-異性体のテイリングがみられるが，両 者の分離注良好である. また回収率の平均値は $m$-異性 体：101.3\%，p-異性体：87.8\% であった。

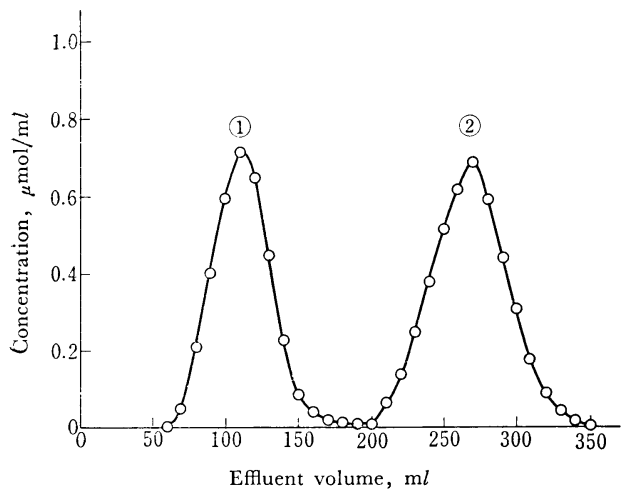

Fig. 7 Elution curves of $m$ - and $p$-aminobenzoic acids

(1) $p$-Isomer ; (2) $m$-Isomer ; Column size : $\phi 17 \mathrm{~mm}$ $\times 230 \mathrm{~mm}$; Developer: Pure water; Flow rate: 0.3 $\mathrm{ml} / \mathrm{min}$; Sample taken : $p$-Isomer $0.04 \mathrm{mmol}, m$ isomer $0.04 \mathrm{mmol}$; Recovery : $p$-Isomer $87.8 \%, m$ isomer $101.3 \%$

\section{5 金属イオンの漏出}

前述のクロマトグラフィーに際して, $\mathrm{Cu}^{2+}$ が樹脂相 から漏出してこないかどうかを確かめるために, pH 8.4 に打いて平衡化させた $\phi 14 \mathrm{~mm} \times 390 \mathrm{~mm}$ の銅 (II) 形の樹脂のカラムに溶離液となる $\mathrm{pH} 8.4$ のアンモニ ア水を流し, 流出液についてジエチルジチオカルバミン 酸法により $\mathrm{Cu}^{2+}$ の定量を行なった。 その結果, 流出 液 $2.0 l$ 中には $\mathrm{Cu}^{2+}$ 注汪とえど検出さ和ず， $\mathrm{Cu}^{2+}$ の 漏出は無視できるものと考元られた。

\section{6 錯体の組成}

3.6.1 液相中における組成 液相中に少いて, $\mathrm{Cu}^{2+}$ に対して 0 -アミノ安息香酸が多量に存在するときには, 溶液の $\mathrm{pH}$ 值が 2.8 以上であれば， 0 -アミノ安息香酸 は $\mathrm{Cu}^{2+}$ と淡緑色の不溶性錯体学生成し, その組成注 $\mathrm{Cu}^{2+}$ に対して 1:2 となることが知られている3 ${ }^{3}$. そ こで $m$ - および $p$-異性体てついても錯体の生成の有無 を調べてみると， pH 5 付近において， m-異性体法緑 色の，また $p$-異性体は暗緑色のいずれも水には不溶の 錯体を形成吉ることが認为られた。これらの錯体を 0.5 $N$ 增酸で分解し, $\mathrm{Cu}^{2+}$ 少よびアミノ安息香酸を定量し てその組成を調べてみると, $m$-異性体では $\mathrm{Cu}^{2+}: m$-ア 乏ノ安息香酸 $=2: 5$ (測定值 $1: 2.46), p$-異性体では
$\mathrm{Cu}^{2+}: p$-ア之ノ安息香酸 $=1: 2($ 測定值 $1: 1.83)$ で あることがわかった。このように $m$-異性体のみがほか の異性体とは異なったタイプの錯体を生成したことにつ いては， $m$-異性体の分子構造が関係しているもの之考 えられる。すなわち，共鳴に対するアるノ基の電子供与 効果を考虑すると，オルトおよびパラ位の - $\mathrm{COO}^{-}$基 の酸素の電子密度は增加するが，メ夕位ではこのような 効果が期待できないので，-COO- 基が反応に関与する と考えると， $m$-異性体の久が異なった挙動を示すこと も理解でき， $m$-異性体の吸着速度が小さかったことと も関連していると考えられる.

しかしながらこれに反して，配位子交換クロマトグラ フィーを実施する場合の条件と同様に, $\mathrm{Cu}^{2+}$ に対して アミノ安息香酸の濃度が低い $\left(\mathrm{Cu}^{2+}\right.$ に対してモル比で 1：1 以下）場合には，各異性体とも不溶性錯体を生成 しなかったが，混合溶液の吸収スペクトル公測定してみ ると，たと光ば o-アミノ安息香酸の場合には Fig. 8 の ようになり，緑色の不溶性錯体とはまた異なった種類の 可溶性錯体の生成が示唆された.

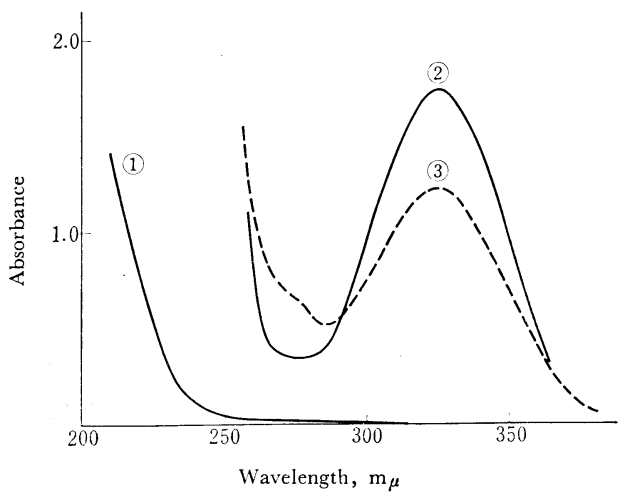

Fig. 8 Absorption spectra of 0 -aminobenzoic acid and its $\mathrm{Cu}^{2+}$ complex in water

(1) $\mathrm{Cu}^{2+}: 1 \times 10^{-3} \mathrm{M}$ (pH 5.5); (2) 0 -Aminobenzoic acid : $1 \times 10^{-3} M(\mathrm{pH} 4.7)$; (3) $\mathrm{Cu}^{2+}+0-\mathrm{ABA}: 1 \times$ $10^{-3} \mathrm{M}$ (mole ratio $\left.=1: 1, \mathrm{pH} 4.7\right)$

このことは $m$ - および $p$-異性体についても同様に認 められた. Fig. 8 より，O-異性体の場合には $270.0 \mathrm{~m} \mu$ に打河光度の増加が，このような可溶性錯体の特性 吸収を示していると考えられた。 $m$-および $p$-異性体の 場合にもそれぞれ $282.0 \mathrm{~m} \mu, 246.0 \mathrm{~m} \mu$ に宗いて吸光 度の増加が観察された。そこでこのような可溶性錯体の 組成を調べるために, $\mathrm{Cu}^{2+}$ を $0.05 \mathrm{mmol}$ 含导溶液 1 $\mathrm{m} l$ にアミノ安息香酸をその当量の $0.25,0.50,0.75$, 
$1.00,1.25$ 倍加え, 水で希䣋して 全量を正確に $50 \mathrm{ml}$ にしたの方 1 時間放置し， $o$-異性体法 $270.0 \mathrm{~m} \mu$ で，ま た $m$ - 異性体は $282.0 \mathrm{~m} \mu$ で，さらに $p$-異性体は 246.0 $\mathrm{m} \mu$ でそれぞれ吸光度を測定し，いわゆるモル比法によ って錯体の組成を調べた，その結果，可溶性錯体の組成 は Fig. 9 より明らかなように，各異性体とも $\mathrm{Cu}^{2+}$ に 対して 1:1であることが明らかとなった。

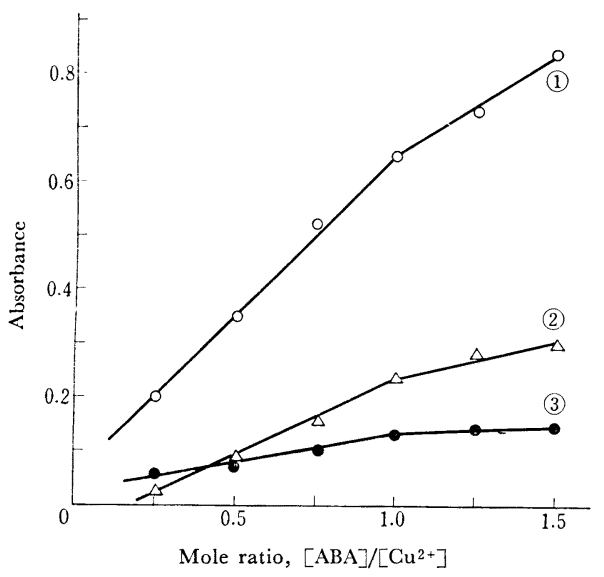

Fig. 9 Composition of $\mathrm{Cu}^{2+}-\mathrm{ABA}$ complex (1) $o$-Isomer (at $270.0 \mathrm{~m} \mu, \mathrm{pH} 4.7$ ); (2) $m$-Isomer (at $282.0 \mathrm{~m}_{\mu}, \mathrm{pH} 4.5$ ); (3) $p$-Isomer (at $246.0 \mathrm{~m}_{\mu}$, pH 4.7); $\mathrm{Cu}^{2+}$ concentration : $1 \times 10^{-3} M$; Solvent : Water

3.6.2 樹脂相中における組成一方，イオン交換樹 脂相中においては， $\mathrm{Cu}^{2+}$ は初め銅アコ錯陽イオンとな って樹脂に保持されているが，溶離液となるアンモニア 水と平衡化させたのちにおいては, 水分子のほかにアン モ二ア分子，水酸イオンも配位して混合錯体になってい るものと考えられる.ただし正確な組成は不明である. しかしながらこの場合, $\mathrm{Cu}^{2+}$ の漏出が認められないこと から， $\mathrm{Cu}^{2+}$ に対して水酸イオンが 2 個以上配位し，生 成する錯イオンの電荷がゼロまたは負になるような状態 は考えられない，このような状態においてアミノ安息香 酸を少量加えると，アミノ安息香酸はすでに $\mathrm{Cu}^{2+}$ に配 位していた水分子，アンモニア分子または水酸イオンと 交換して樹脂に捕集されることになるが，この場合もア ミノ安息香酸アニオンが 2 個以上配位した状態は考えら れず，しかもアミノ安息香酸アニオンが 1 個配位した場 合には水酸イオンが配位した状態は考えられない.そこ で実際に $1 \mathrm{~g}$ の銅 (II) 形樹脂 $\left(\mathrm{Cu}^{2+} 2.56 \mathrm{mmol}\right.$ 含む）を詰めた外径 $6 \mathrm{~mm}$ のカラムに $0.5487 \mathrm{mg} / \mathrm{ml}$ の濃度のアミノ安息香酸溶液 $500 \mathrm{ml}$ を流し, 樹脂相中
で生成する錯体の組成を検討した結果， 0 -異性体の場合 にはその $158.9 \mathrm{mg}$ が捕集されて樹脂は淡緑色となり， 樹脂中の $\mathrm{Cu}^{2+}$ に対してモル比で 1:0.45 となっている ことがわかった。 o-異性体の場合には $\mathrm{Cu}^{2+}$ の漏出は認 められなかったが， $m$ - および $p$-異性体の場合には樹脂 はやはり緑色となり，明らかに錯体の生成が観察された が， $\mathrm{Cu}^{2+}$ の漏出が認められ，さらに流出液中において も緑色の不溶性錯体が生成したので，正確な吸着量およ びモル比は不明であった。したがって $m$-および $p$-異性 体の場合には液相中における場合と同様に電荷がゼ口ま たは真の錯体が生成したものと考えられる。しかしなが ら，クロマトグラフィーに際してはアミノ安息香酸の添 加量が少ないので，樹脂相中ではどの異性体の場合も， $\mathrm{Cu}^{2+}$ に対しては 1:1 以下になるものと考えてさしつ かえないと思われる.このことは，o-異性体の場合は前 述の実験結果から明らかであり，m-および $p$-異性体の 場合は分配係数が非常に小さいことからも推察できる.

これと同時に， $m$-および $p$-異性体の分配係数が $o$ - 異 性体に比べて著しく小であったことに着目すると， $m$ および $p$-異性体の分離が 純水で展開溶離することによ って可能であったことともあいまって，m-および $p$-異 性体の銅 (II) 形樹脂に対する吸着は単なる分子吸着で はなからうかと考えることもできる.しかし純水中で膨 潤させただけの銅（II）形樹脂（液相の $\mathrm{pH}$ は 5 前後と なる）のカラムにはじめから $m$ - および $p$-アミノ安息 香酸溶液を流し, 純水で溶離してもなかなか溶出せず, 3.4 .3 に述べた方法によってはじめて溶出してくること から，m-抢よび $p$-異性体の吸着はやはり配位子交換反 応によるもので，はじめに $\mathrm{Cu}^{2+}$ に配位していたアンモ ニア分子もしくは水酸イオンとの交換によるものと考え られる. これに対して 0 -異性体の場合には，アンモ二 ア水を用いないと溶出してこないことから，明らかにア ンモニア分子または水酸イオンとの配位子交換と考える ことができる。

\section{7 溶離剈の影響}

配位子交換反応は一種の錯体分解反応であるが，0-巽 性体をアンモニア水で溶離する場合, 水酸イオンとアン モニア分子のう台のいずれが重要な役割を果たしている かを調ベるために，アンモニア水打よび水酸化ナトリウ ム水溶液中に㧍いて 銅-O-アミノ安息香酸錯体の安定性 を検討してみた。すなわち, $\mathrm{Cu}^{2+}$ および 0 ○アうノ安息 香酸の濃度がそ机ぞれ $1 \times 10^{-4} M$ になるように $\mathrm{Cu}^{2+}$ とoーアミノ安息香酸を混合し, これに $6 N$ のアンモニア 水をた法水酸化ナトリウム水溶液をごく微量加えて溶液 
の $\mathrm{pH}$ が 10.0 になるように調整した． そののち一定 時間放置してから， pH ならびに $270.0 \mathrm{~m} \mu$ における吸 光度を測定し， $\mathrm{pH}$ と吸光度の 経時変化を調べたとこ ろ，Fig. 10 のようになった。

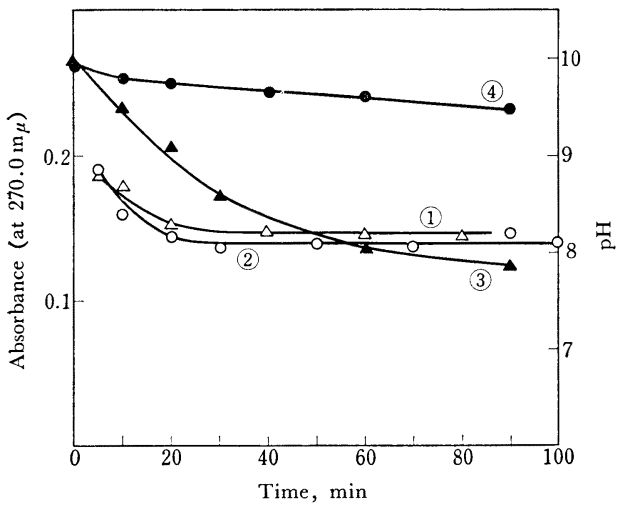

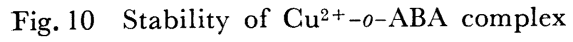

(1) In $\mathrm{NaOH}$ solution; (2) In aqueous ammonia ; (3) $\mathrm{pH}$ variation curve of (1); (4) $\mathrm{pH}$ variation curve of (2)

Fig. 10 より, 吸光度はいずれの場合もはじめの 30 分 間に急激に減少するが，30 分を経過するとほとんど変 化しなくなることが認められる。このことは銅-o-アミ ノ安息香酸錯体の分解が主として水酸イオンによって推 進されることを示しており，しかも 0 -アミノ安息香酸 イオンと水酸イオンとの交換は比較的すみやかに起こる ことをも示している.しかしながら，アンモニア水を用 いた場合には水酸化ナトリウム水溶液を用いた場合より も，わずかながら分解速度が大きいことから，アンモニ ア分子もまた銅ー0ーアミノ安息香酸錯体の分解に影響を 及ぼしていることが推察されるが，その分解機構は明確 ではない。

一方, 液相の $\mathrm{pH}$ 值も時間の経過とともに減少し, 水 酸イオンが $\mathrm{Cu}^{2+}$ に捕そくされることが認められたが， $\mathrm{pH}$ 值の減少のしかたはアンモニア水の場合と水酸化ナ トリウム水溶液の場合とでは明らかに異なり，前者の場 合のほうがゆるやかであった。これは強電解質と弱電解 質との違いに基づくもののほかに, 水酸イオンよりもア ンモニア分子のほうが $\mathrm{Cu}^{2+}$ に配位しやすいことにも関 係があると考えられる。

以上の検討結果よりみれば，o-異性体の溶離にはアン モニア水の代わりに水酸化ナトリウム水溶液を用いるこ ともじゅうぶえに可能であると考えられる. そこで水酸 化ナトリウム水溶液中において, $\mathrm{pH} 9.4$ で平衡化させ
た銅（II）形樹脂を用いて $\phi 17 \mathrm{~mm} \times 230 \mathrm{~mm}$ のカラ ムを作製し，これに 0 - および $m$-異性体をとれでれ $0.02 \mathrm{mmol}$ ずつ含む試料液 $1 \mathrm{ml}$ 学添加したのち, $\mathrm{pH}$ 9.4 の水酸化ナトリウム水溶液を $0.3 \mathrm{ml} / \mathrm{min}$ の流速で 流して溶離を行なった.この場合のクロマトグラム注 Fig. 11 のようである.

Fig. 11 より，水酸化ナトリウム水溶液を用いた場合 にも，o-異性体は比較的す夕やかに溶出し，かつ 0 - お よび $m$-異性体の分離浣全であることが垫められ，前 述のように水酸イオンがこの場合の配位子交換反応にあ ずかって重要な役割を果たしていることが確かめられ た.しかしながら, Fig. 11 と Fig. 5 を比較した場合, 水酸化ナトリウム水溶液を使用した場合には，カラムの 大きさも小さく，しかも水酸イオンの濃度もアンモニア 水を使用した場合よりも高いにもかかわらず，o-異性体 の保持容量が大になっていることから，アンモニア分子 の影響もはなはだ重要であると考えられる。したがって 溶離液としては水酸化ナトリウム水溶液よりもアンモ二 ア水のほうが，より有効であると考えられる。なお， Fig.11 の条件での $\mathrm{Cu}^{2+}$ の漏出はほとえど認められな かった。

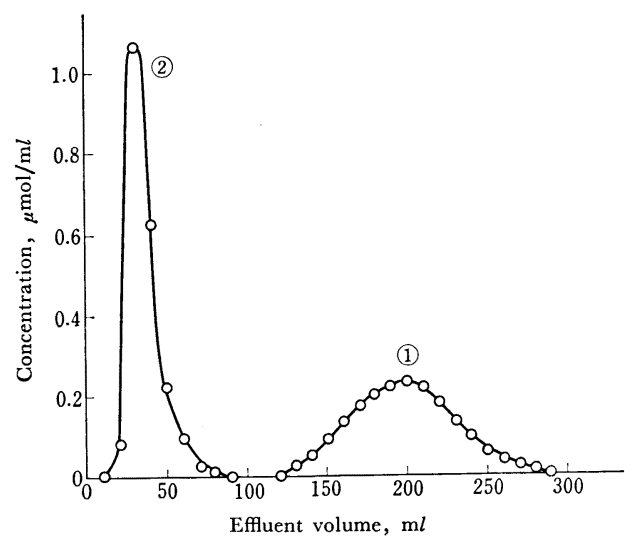

Fig. 11 Elution curves of $o-$ and $m$-aminobenzoic acids using $\mathrm{NaOH}$ solution as a developer (1) o-Isomer ; (2) $m$-Isomer ; Column size ; $\phi 17 \mathrm{~mm}$

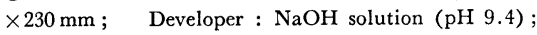
Flow rate : $0.3 \mathrm{ml} / \mathrm{min}$

\section{8 総 括}

3 種類のアミノ安息香酸異性体は, 水溶液中におい て， $\mathrm{Cu}^{2+}$ とそれぞれ異なった組成をもつ緑色の不溶性 錯体を生成するが， $\mathrm{Cu}^{2+}$ に対してアミノ安息香酸の濃 度が低い場合には，この緑色錯体とはまた別の無色の可 溶性錯体を生成した。このことを利用して，銅 (II) 形 
の強酸性樹脂を詰めた $\phi 14 \mathrm{~mm} \times 390 \mathrm{~mm}$ のカラムなら びに pH 8.4 のアンモニア水を溶離液に使用する配位子 交換クロマトグラフィーにより，アミノ安息香酸異性体 を分離する力法について検討し，好結果を得た。 またこ の場合, 溶離液としてアンモニア水の代わりに水酸化ナ トリウム水溶液を使用することの可能性も見いだした.

(昭和 44 年 4 月, 日本化学会 22 年会に打いて一部講演)

\section{交献}

1) 舟阪 渡, 藤村一美, 栗山 智 : 本誌, 18, 19 (1969).

2) H. Funk, M. Ditt : Z. anal. Chem., 91, 332 (1933).

3) 後藤秀弘：日化, 55, 1156 (1934).

4) L. Reio : J. Chromatog., 1, 338 (1958).

5) M. Viettri-Michelina : Rass. Chim., 10, 13 (1958); Chem. Abstr., 54, 3038 (1960).

6) 舟阪 渡, 小島次雄, 藤村一美 : 本誌, 14, 820 (1965)

$$
\text { is }
$$

Separation of aminobenzoic acid isomers by ligand exchange chromatography. Wataru FunAsaka, Kazumi Fujimura and Satoshi Kuriyama (Department of Industrial Chemistry, Faculty of
Engineering, Kyoto University, Sakyo-ku, Kyotoshi)

A method of chromatographic separation of aminobenzoic acid isomers, in which a sulfonated cation exchange resin Amberlite GG-120, Cu(II) form, was used as a stationary phase and aqueous ammonia as a developer, was investigated.

Studies on the adsorption of the three isomers to the resin in aqueous ammonia showed that (a) the $K_{d}$ value of each isomer decreased with increasing concentration of ammonia, (b) the $K_{d}$ value of 0 isomer was much larger than that of $m$ - or $p$-isomer at a pH range from 8.0 to 10.0 because of the formation of a stable complex and (c) the rate of adsorption and desorption of $m$-isomer was different from that of $o$ - or $p$-isomer probably because of the difference in composition of the complex.

The separation of $o-$ and $m$-isomers or of $o-$ and $p$-isomers was successfully achieved when a mixture was eluted through a column of $\phi 14 \mathrm{~mm} \times 390 \mathrm{~mm}$ with aqueous ammonia of $\mathrm{pH} 8.4$ at a flow rate of $0.3 \mathrm{ml} / \mathrm{min}$., but $m$ - and $p$-isomers could not be separated except when pure water was used as a developer.

From the studies on the stability of $\mathrm{Cu}-0$-aminobenzoic acid complex in $\mathrm{NaOH}$ solution of $\mathrm{pH} 10.0$, it was found that $\mathrm{NaOH}$ solution also was useful as a developer for separating $o-$ and $m$ - or $o-$ and $p$ isomers.

(Received July 29, 1969) 